\title{
Coral Recruitment Spatial Distribution in its Relation With Coral Cover and Herbivorous Fish Abundance Within Conservation Area
}

\author{
Zulfikar Afandy ${ }^{1 *}$, Ario Damar ${ }^{1}$ and Syamsul Bahri Agus ${ }^{2}$ \\ ${ }^{1}$ Department of Aquatic Resources Management, Faculty of Fisheries and Marine Science, \\ Bogor Agricultural University \\ 2Department of Marine Science and Technology, Faculty of Fisheries and Marine Science, \\ Bogor Agricultural University \\ JI, Raya Dramaga, Kampus IPB, Bogor, Indonesia 16680 \\ Email: zulfikarafandy@gmail.com
}

\begin{abstract}
The continuity of coral reef ecosystem highly depends on the new coral larvae recruitment process. Hence, the information regarding distribution, the abundance of corals, and its relation to other variables are highly important in that ecosystem management. Research was conducted at nine stations represented each zone at the conservation area of Kapoposang Marine Tourism Park (TWP Kapoposang). This research aims at seeking for spatial variations of the abundance of coral recruitment at three primary zones monitored (core zone, sustainable fishing zone and utilization zone) and we further identified its relations with spatial variation of herbivorous fishes abundance and coral cover's condition at those zones. The coral recruitment observation employed transect quadrat sampling method with size of $1 \times 1$ meter and 10 times repetition at a similar depth, and the coral recruitment abundance measurement in natural habitat based on the amounts of juvenile corals has been defined as coral colony with size of $\leq 10 \mathrm{~cm}$. Overall, this research has found 534 coral juveniles consisted of 19 genera and 7 families, and the average of juvenile coral density stood at $5.34 \pm 4.45$ SE. $\mathrm{m}^{-2}$. The coral reef recruitment category at TWP Kapoposang could be classified as high and its abundance spatial distribution showed no significant differences between each zone, as well as not influenced by either herbivorous fish abundance variable or the percentage of live coral cover.
\end{abstract}

Keywords: coral reef, sustainability, marine protected area, abundance

\section{Introduction}

The establishment of the Marine Protected Area $(\mathrm{KKP})$ is one of the important tools that has been widely used in natural resources and ecosystem management. The coral reef as one of the vital objects within the KKP is very prone towards the increasing of anthropogenic pressures as well as the impact of climate change such as the increase of sea levels, sea warmth, and acidity.

Coral larvae recruitment process is one of the vital issues in the management and coral reef conservation. Besides being the most important feature of the population dynamic that ensures the continuity and the restoration of coral reef (Abelson et al., 2005; Bachtiar, et al., 2012; Hughes and Tanner, 2000; Moulding, 2005), the recruitment process also proves that there is a connectivity between coral reef (Bellwood et al., 2004; Cowen, 2006)as well as reflecting the occurance of coral resiliency process in recovering (Hughes et al., 2007; McClanahan et al., 2012).
Previously, there were several coral recruitment research carried out in Indonesia, among others are Fox (2004) who conducted his research in the Komodo National Park. He compared the coral recruitment in an area that previously blasted by fish bomb and in an area that free from fish bombing or other destructive fishing activities. Singkoh (2010) had conducted an interaction analysis of coral recruitment based on the quantity, depth, and sites in Bunaken Islands. Abrar et al., (2011) conducted a research on the survival rate and the growth rate of coral recruitment in Pari Islands, Kepulauan Seribu, Jakarta. On the other, research about coral recruitment diversity and coral recruitment abundance had also been held in Kendari (Palupi et al., 2012), Lembata (Bachtiar et al., 2012) and in Lovina Tourism Beach, Bali (Dodik, 2012). De Leon et al. (2013) also saw a temporary variation and spatial recruitment in Hoga reef and in Sampela, Wakatobi. Meanwhile Abrar (2015), while researching about the abundance and the density of coral recruits, $\mathrm{He}$ also analyzed the relations between adult coral and algae cover. 
Aside from examining the diversity and the abundance of coral recruitment in each site, the research we conducted also seek to measure the relations between coral recruitment abundance with live coral cover as well as the herbivorous fish abundance. Not only carrying important roles in managing the structure of the coral reef community, (Husain and Gardiner, 2014), the herbivorous fishes also function in limiting the growth of algae communities which will further ensure the coral reef resiliency (Green and Bellwood, 2009). In addition, the abundance of herbivorous fishes also highly corresponds with the coral recruitment abundance (Khalil, 2011) that clearing the substrate and provide places for corals' planula to stick and to develop (Bellwood et al., 2004).

This research aimed at analyzing the spatial variations of coral reef recruitment abundance at three sites covered at TWP Kapoposang (core zone, sustainable fishery zone and utilization zone). We conducted this research by linking the observation with the spatial variation of the herbivorous fish abundance and the coral cover condition at those zones.

\section{Materials and Methods}

The Kapoposang Marine Tourism Park (TWP Kapoposang) is located in the Spermonde Islands and is administratively within the Pangkep District, South Sulawesi Province, Indonesia (Figure 1.). The area of TWP Kapoposang Islands spans over 50,000 ha, covering six islands including Kapoposang Makassar Strait, and its location is highly influenced Islands, Papandangan Islands, Pamanggangan Islands, Tambakulu Islands, Gondongbali Islands, and Suranti Islands. TWP Kapoposang geographically sits out in the outer ring of Spermonde archipelago, which sprawls off the by the climate and the ocean current patterns of the Makassar Strait

This research was conducted in September 2016 at nine stations represented each zone of TWP Kapoposang. Those zones are Core Zone (ZI) consisted of three stations: Suranti 1 (SR1), Suranti 2 (SR2) and Pattalibboang (PTB). The Sustainability Fishing Zone (PB) represented by Gondongbali station (GDB), Pattilingan (PTL) station and Tanjung (TJG) station. And the Utilization Zone (ZP) which comprised of Taka Palekko1 station (TP1), Taka Palekko2 (TP2) and Taka Pallawangang (TPG) station.

\section{Coral recruitment}

The coral recruitment observation had used transect quadrat sampling method with size of $1 \times 1$ meter for as much as ten repetitions and within an interval range of 5 meter at similar depth. The measurement of coral recruitment abundance was based on the amount of coral larvae or juvenile defined as coral colony sized $\leq 10 \mathrm{~cm}$ (Obura and Grimsditch, 2009). The identification included the

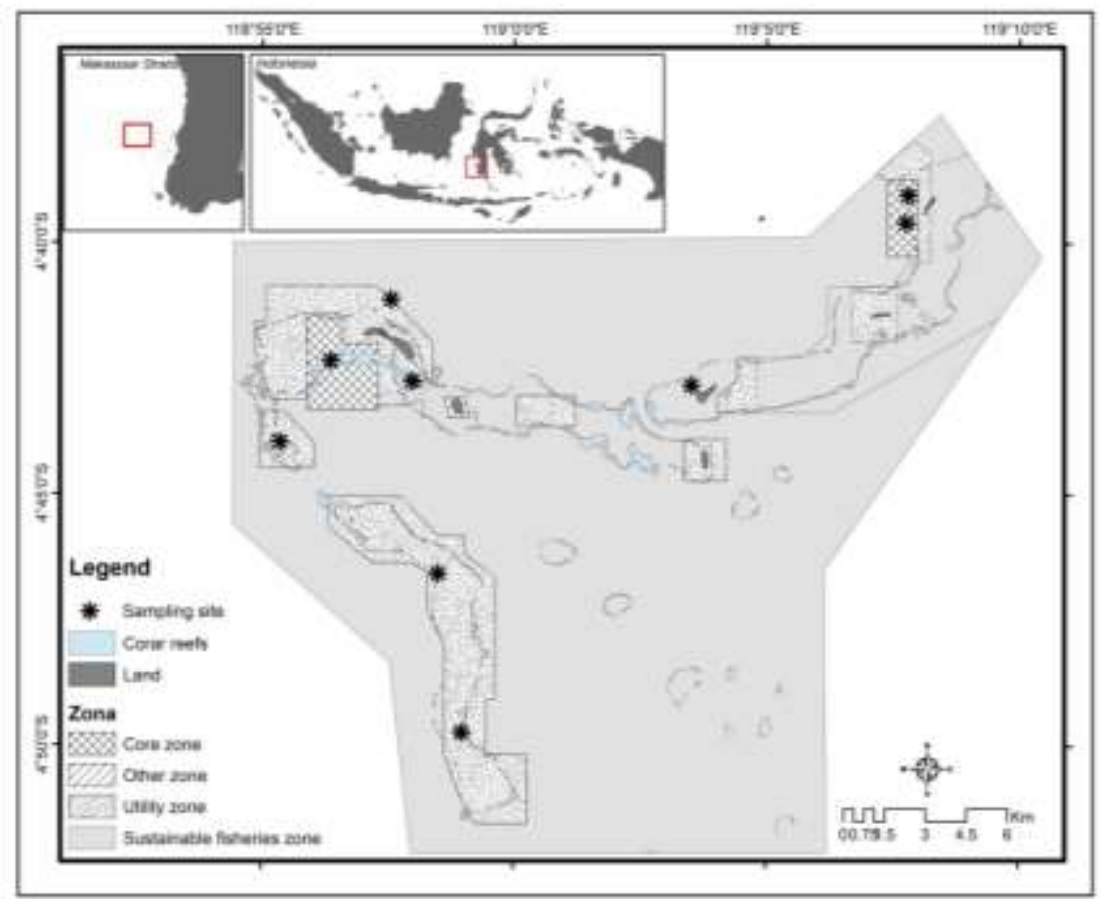

Figure 1. Research Location at Kapoposang Marine Tourism Park, South Sulawesi Province 
colony number and the type of substrate found at the bottom of the water. The identification was conducted on-site supported by underwater pictures that to be further identified. The identification itself was conducted until the genus stage by referring to Kelley (2011) and Suharsono (2008). The status of coral recruitment based on Obura and Grimsditch, (2009) categories.

\section{The coral reef condition}

The observation of coral reef condition was conducted by utilizing the Underwater Photo Transect (UPT) method. The image was captured at an interval range of 1 meter along of the transect lines located at the station points within the depth between 5-7 $\mathrm{m}$. The result of the transect pictures were further analyzed by using the CPCe version 4.1 software (Kohler and Gill, 2006). The analysis technique chose sampling points at 20 random areas. The coral reef condition category was determined based on the number of live coral covers percentage as stipulated in the Ministerial Regulation No. 04 Year 2001 on the Guideline Criteria of the damages to coral reef ecosystem issued by the Ministry of Environment and Forestry (MENLH, 2001).

\section{Herbivorous fish}

The classification of the herbivorous fishes was based on the ecological function of each of the species. The fish communities included in the herbivorous group were family of Scaridae, Achanthuridae and Siganidae (Giyanto et al., 2014). The fish observation was conducted by utilizing the Underwater Visual Census (English et al., 1997). The UVC method employed transect lines as long as 50 meters. The identification of all of the herbivorous fish species also included those fishes found as far as 2.5 meters to the left and 2.5 meters to the right of the transect lines. The fish species identification itself was based on Allen et al (2003). The benchmarks of the coral fish community are those commonly used community benchmarks, including the number of species (taxa), the abundance of individuals and the species diversity.

\section{Statistical analysis}

To examine the average differences of the coral recruitment, coral condition and the herbivorous fish abundance on each of the observed sites, we employed the ANOVA test. Meanwhile, to analyze the relation between the abundance of coral recruitment and the percentage of coral cover as well as the abundance of herbivorous fishes, we used the Pearson Correlation Test.

\section{Results and Discussion}

\section{Coral juvenile}

This research has found that there were 534 coral juveniles that consisted of 19 genera and 7 families. Among all of the stations observed, the average density of coral juvenile was $5.34 \pm 4.45$ SE. $\mathrm{m}^{-2}$, based on the category Obura and Grimsditch (2009). Hence, the coral recruitment rate at TWP Kapoposang could be classified as high. Meanwhile, a research conducted by Sawall et al. (2013) in several islands in the Spermonde islands found that the recruitment rate was medium. The differences in the result of these two research were might be due to the different methods employed.

The coral juvenile density was highly varied between zones. Meanwhile, the core zone's coral recruitment abundance rate recorded at $6.03 \pm 1.30$ colony. $\mathrm{m}^{-2}$, the rate at the sustainable fishing zone stood at $6.73 \pm 4.83$ colony. $\mathrm{m}^{-2}$ and the rate at the utilization zone was recorded at $4.47 \pm 0.91$ colony. $\mathrm{m}^{-2}$ (Figure 2A.). The coral juvenile abundance was dominated by four genera (Acropora, Fungia, Porites and Seriatopora) covered $76.8 \%$ of the total of coral juveniles identified. Genus Fungia dominated the abundance at the core zone (accounted for $47.7 \%$ ) and at the sustainable fishing zone for $43.6 \%$, meanwhile genus Porites dominated the utilization zone and accounted for $50 \%$ of the total genus existed (Figure 3A.). The coral recruitment rate at each zone looked vary, but based on the ANOVA test $(P=0.85)$, the number of coral recruitment genus at those three zones of TWP Kapoposang did not particularly show significant differences. We argue that this might be due to the similarity of the factors that influence the coral recruitment, including the availability of parents as larvae sources, substrates in a form of habitat variations, as well as the water dynamics such us current, temperature, and light (Abrar, 2015). At the local factor scales influencing it also tend to be similar, hence the coral recruitment patterns that took place were also relatively similar and consistent (De Leon et al., 2013).

\section{Live coral covers}

The coral condition classification at TWP Kapoposang were damaged to very good condition based on the station observation findings $(2.40 \%$ $90.48 \%)$, the average of live coral cover was recorded at $41.19 \pm 11.45 \%$. This condition was similar with the result found by Papu (2011) which his survey obtained an average value of live coral cover amounted for $48.53 \%$. Meanwhile, the coral cover condition was varied on each zone, they were 
recorded at $6.32 \pm 2.60 \%$ at the utilization zone, $46.78 \pm 16.50 \%$ at the sustainable fishing zone and $70.47 \pm 15.35 \%$ at the core zone (Figure 4.). The coral abundance was dominated by four growth model types (Acropora branching, Coral branching, Coral foliose and Coral massive), which consisted of $83.17 \%$ of the total corals identified (Figure 2B.). Acropora branching consisted of Genus Acropora was identified dominating the abundance at the core zone (accounted for $36.55 \%$ ), meanwhile at the two remaining zones, the sustainable fishing zone and the utilization zone, the Coral massive accounted for $26.75 \%$ and $52.76 \%$, consisted of Genus Porites, Goniastrea and Pavona all dominated the growth model at those zones.

Based on the ANOVA result, it indeed recorded significant differences on the coral condition between zones $(P=0.05)$. The high percentage of the live coral cover at this core zone has also supported the spillover function to the other zones. This condition further supports the role of the core zone as a larvae source as it allows connectivity to occur, considering that the ability to repair (resilience) from coral reef within a region depends on the connectivity efficiency between coral reef in that conservation area (Underwood et al., 2013). The low percentage level of coral cover at the utilization zone (Figure 4.) is expected to recover in the years to come, and new coral recruitment could be derived from the other zones that have good level of coral cover percentage. Asides from that, the herbivorous fish abundance rate recorded at this zone was also considerably high. The recovery process of the conditions of the coral highly depends on the connectivity rate between corals which also will positively impact the coral recruitment rate (Hogan et al., 2012) as well as the abundance of herbivorous fishes community (Bellwood et al., 2004; Hughes et al., 2007).
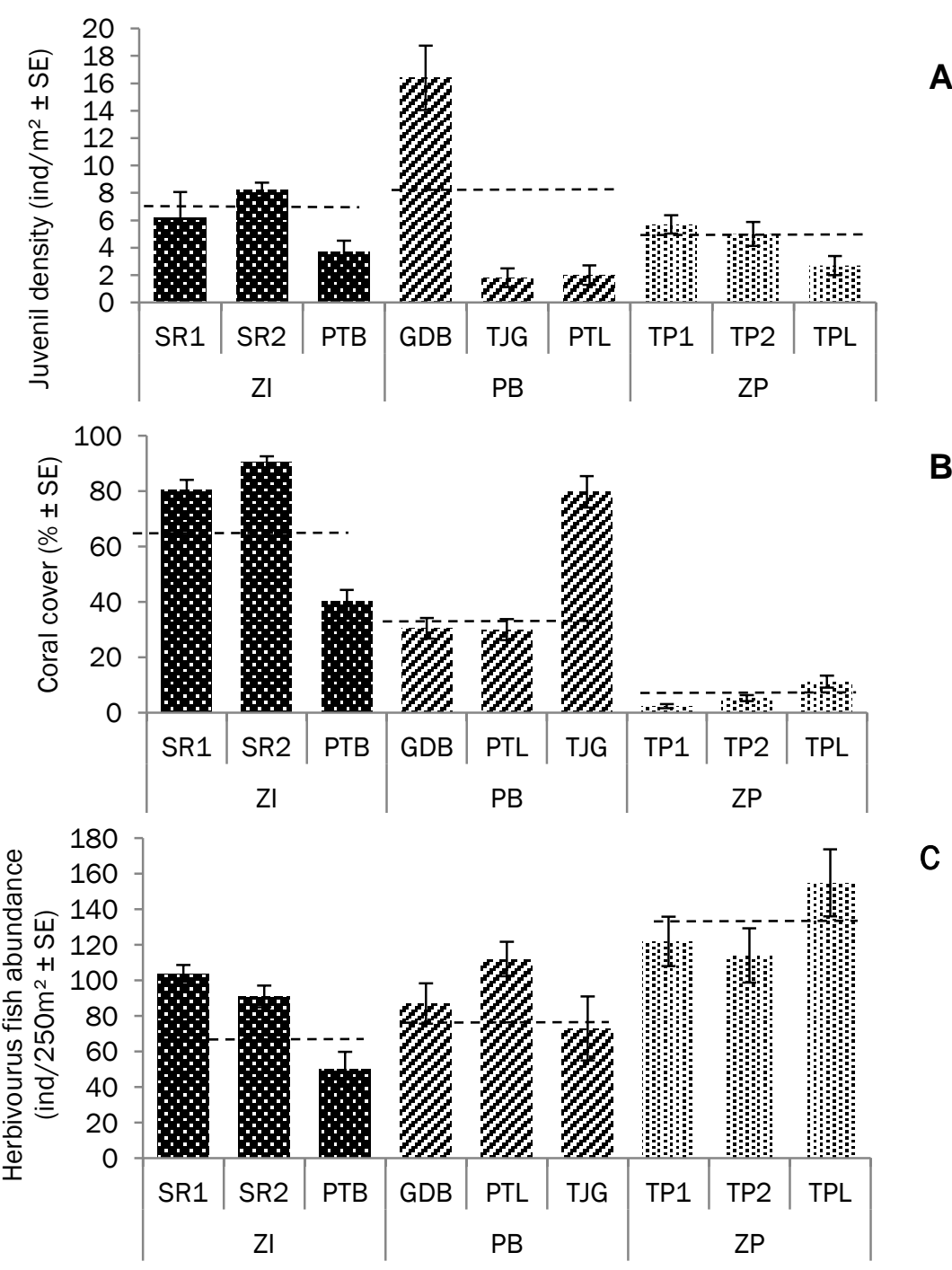

Figure 2. The average of (A) coral juvenile abundance; (B) Coral cover; and (C) Herbivorous Fishes abundance at three zones studied at TWP Kapoposang 

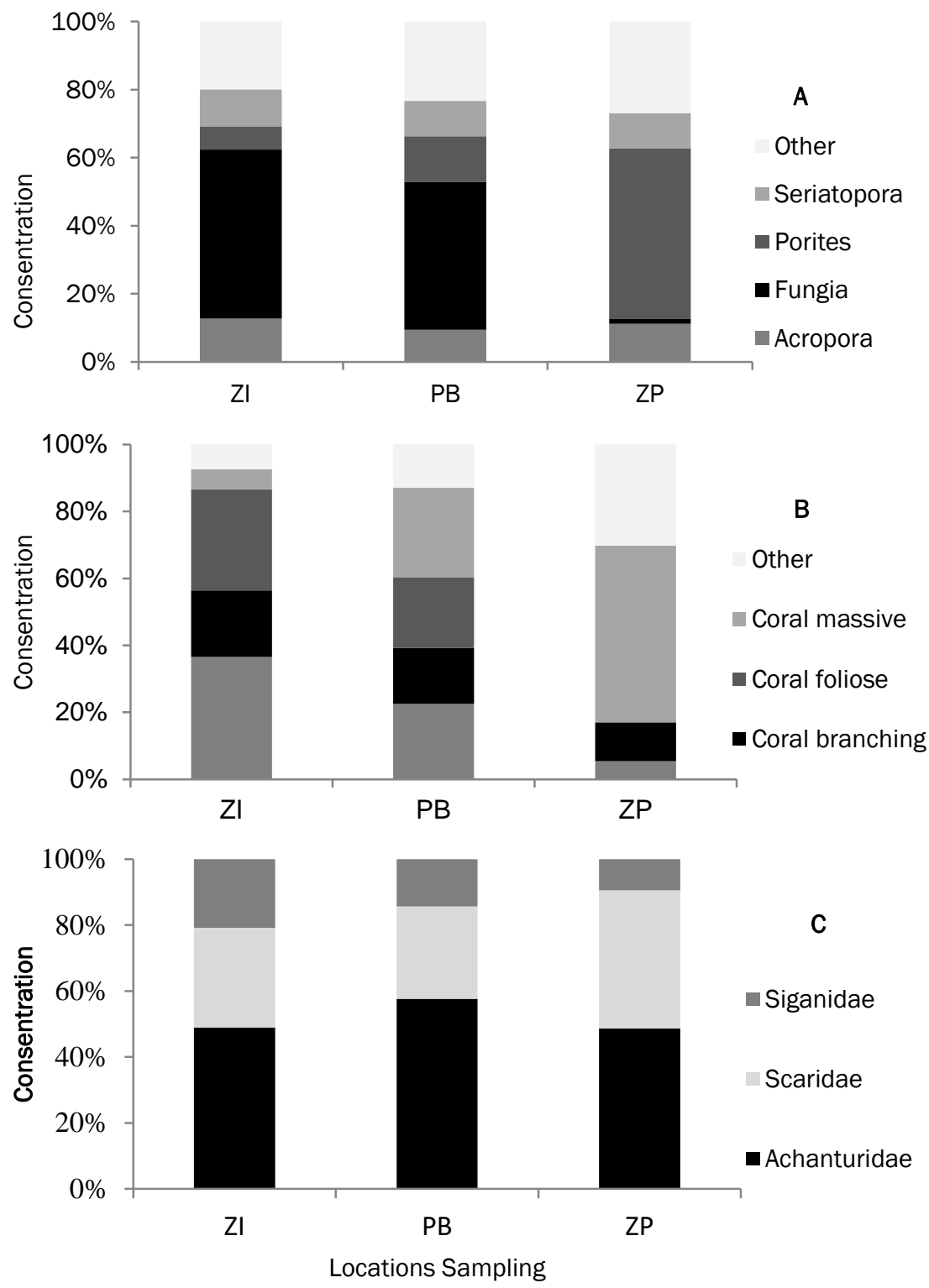

Figure 3. The proportion of (A) Coral juvenile genus; (B) Growth Type; (C) Herbivorous fish genus at three zones studied at TWP Kapoposang.

\section{Herbivorous fish abundance}

The total of herbivorous fish abundance found amounted for 1,038 individuals, 34 species and 8 genera. The family of Achanturidae has dominated the herbivorous fish abundance at each zone, where the abundance proportion rate at the core zone, the sustainable fishing zone, and the utilization zone was recorded at $48.98 \%, 57.67 \%$, and $48.62 \%$, respectively (Figure $2 \mathrm{C}$.).

The highest number of total abundance recorded at the utilization zone was 391 individuals, this was caused by the abundance of algae that significantly high at the zone, as also shown by the high Death Coral Alga (DCA) value compared to the other zone (unpublished). This as well in line with the data found by Russ (2003) on his research at the Great Barrier Reef.Russ (2003) argued that no significant relations between the algae abundance and the herbivorous fishes. However, according to Husain and Gardiner (2014), the abundance distribution and the herbivorous fish biomass at the Spermonde Islands did not solely depend on the algae's condition but also was largely influenced by the fishing activities at the area.

There were no significant differences on the coral fish abundance between zones $(P=0.05)$, and the highest abundance rate found at the utilization 
zone was accounted for the average total of $130.33 \pm 12.55$. Meanwhile, the core zone recorded the abundance rate of $81.67 \pm 16.27$ and at the sustainable fishing zone at $90.67 \pm 11.41$ (Figure 2C.). Although there were no significant differences, the abundance of herbivorous fishes looked vary along the zones, this in line with the previous findings byNemeth and Appeldoorn (2009) who argued that the herbivorous fishes could disperse along the coast or highly depend on the water depth as well as the different circumstances surrounding the coral habitats.

\section{The relations between variables}

Although that the live coral cover is one of the factors affecting the coral recruitment (Hughes et al., 2000), but referring to the Pearson correlation test conducted at this research, the relation between juvenile coral variables and the live coral cover was particularly low $(P=0.03)$, the high influence of live coral cover towards coral juvenile abundance rate amounted for only $0.1 \%\left(\mathrm{R}^{2}=0.001\right)$. A research
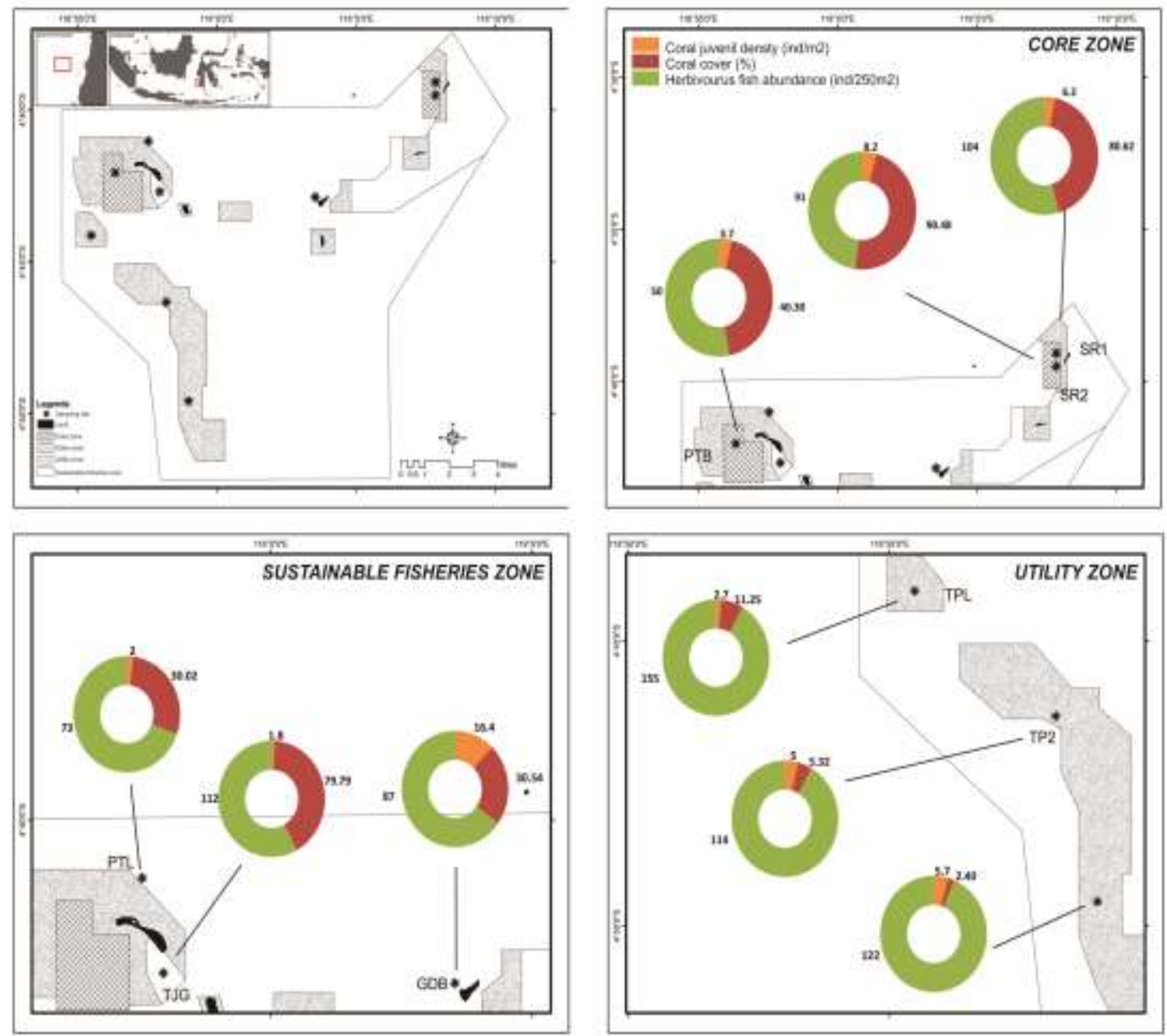

Figure 4. The spatial dispersion of coral recruitment abundance variable, coral cover and the herbivorous fish abundance at each zone of TWP Kapoposang

carried out by Abrar (2015) also found a slightly low influence between coral juvenile and live coral cover $\left(R^{2}=0.077\right)$. The Figure 5 shows the differences between coral cover percentage and coral recruitment abundance found at the utilization zone, the data recorded low percentage of coral cover but the coral recruitment abundance was not significantly differed from the other zones. Hence, this shows us that the locations with low percentage of coral cover are not always followed by low rate of coral recruitment abundance, De Leon et al. (2013) also suggested that the locations with low percentage of coral cover are not always run out of larvae supply. Those zones might likely obtain their larvae supplies from the other zones, considering that the transport of larvae could occur from one location to the other through ocean currents (Underwood et al., 2013).

Coral Recruitment is strongly influenced by the herbivorous fish community, where healthy herbivorous fish communities are essential in the process of reef restoration. Based on Pearson

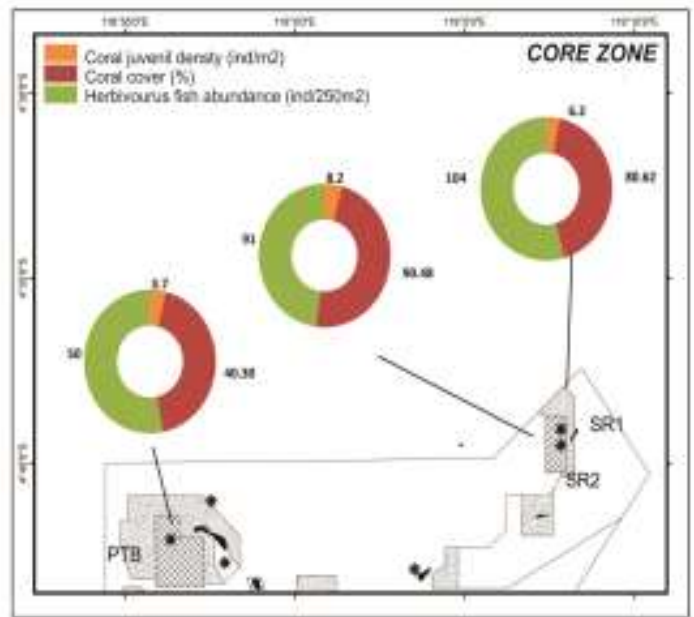


correlation test results obtained the relationship between juvenile coral and herbivorous fish abundance negatively correlated $(-0.17)$, and the magnitude of the effect of herbivorous fish abundance on juvenile corals by $2.8 \%\left(R^{2}=0.028\right)$, this shown the effect of fish abundance variables Herbivores were not significant to the abundance of juvenile corals. The same statement by Trapon et al. (2013) in his study found no significant relationship between Scaridae fish with abundance of juvenile corals in the Great Barrier Reef. However, the opposite statement by Hughes et al. (2007) that decreased algae cover and increased coral cover were more rapid with the presence of herbivorous fish. This occurs when herbivorous fish eat algae on the surface of the reef, indirectly providing new space for juvenile corals to stick and grow into new individuals.

\section{Conclusions}

There was no differences on the spatial distribution of coral recruitment between zones at TWP Kapoposang. There was no effect of herbivorous fish and the percentage of live coral cover to the coral juvenile abundance rate. In addition, coral recruitment process also plays an important role in preserving the sustainability of coral reef ecosystem. Understanding the recruitment patterns and factors that affect them becomes highly critical especially in constructing the management plan of TWP Kapoposang in the future.

\section{Acknowledgements}

The authors thank to the research and human resources of ministry of marine and fisheries (BRSDMKP) who have funded this research, and to the satker TWP Kapoposang for the assistance of facilities during the research.

\section{References}

[MENLH] Menteri Negara Lingkungan Hidup. 2001. Keputusan Menteri Negara Lingkungan Hidup No . 4 Tahun 2001 Tentang: Kriteria Baku Kerusakan Terumbu Karang.

Abelson, A., Olinky, R. \& Gaines, S. 2005. Coral Recruitment to The Reefs of Eilat, Red Sea: Temporal and Spatial Variation, and Possible Effects of Anthropogenic Disturbances. Mar. Poll. Bull. 50(5):576-582. doi: 10.1016/j. marpolbul.2005.02.021

Abrar, M. 2015. Karang Keras Rekruitmen (Sceractinia) di Perairan Natuna, Provinsi
Kepulauan Riau. Oseanol. Limnol. Indonesia. 41(2): 133-147.

Abrar, M., Zamani, N.P. \& Wayan, I. 2011. Coral Recruitment , Survival and Growth of Coral Species at Pari Island, Thousand Islands, Jakarta: A Case Study of Coral Resilience. J. Ind. Coral Reefs. 1(1): 7-14. doi: 10.1017/CB097 81107415324.004

Allen, G., Steene, R., Humann, P. \& Deloach, N. 2003. Reef Fish Identification - Tropical Pacific Fishes. New World Publication.

Bachtiar, I., Abrar, M. \& Budiyanto, A. 2012. Rekruitmen Karang Scleractinia di Perairan Pulau Lembata. IImu Kelautan. 17(1): 1-7.

Bellwood, D. R., Hughes, T. P., Folke, C., \& Nyström, M. 2004. Confronting The Coral Reef Crisis. Nature, 429(6994):827-833. doi: 10.1038/ nature02691

Cowen, R.K. 2006. Scaling of Connectivity in Marine Populations. Science. 311(5760): 522-527. doi: 10.1126/science.1122039

De Leon, S.P., Dryden, C., Smith, D.J. \& Bell, J.J. 2013. Temporal and Spatial Variability in Coral Recruitment on Two Indonesian Coral Reefs: consistently lower recruitment to a degraded reef. Mar. Biol. 160(1):97-105. doi: 10.1007/ s00227-012-2066-7)

Dodik, I.N.P. 2012. Rekrutmen Karang di Kawasan Wisata Lovina. Sains Dan Teknologi. 1(2):6172.

English, S., Wilkinson, C. \& Baker, V. 1997. Survey Manual For Tropical Marine Resources. Townsville: Australian Institute of Marine Science.

Fox, H.E. 2004. Coral Recruitment in Blasted and Unblasted Sites in Indonesia: Assessing Rehabilitation Potential. Mar. Ecolog. Prog. Ser. 269: 131-139. doi : 10.3354/meps269131

Giyanto, Manuputty, A.E., Abrar, M., Siringoringo, R. M., Suharti, S.R., Wibowo, K., Edrus, I N., Arbi, U.Y., Cappenberg, H.A.W., Sihaloho, H.F., Tuti, Y. \& Zulfianita, D. 2014. Panduan Monitoring Kesehatan Terumbu Karang. Jakarta: LIPI.

Green, A.L. \& Bellwood, D.R. 2009. Monitoring Functional Groups of Herbivorous Reef Fishes as Indicators of Coral Reef Resilience A practical guide for coral reef managers in the Asia Pacific Region (7). Gland, Switzerland. 
Hogan, J.D., Thiessen, R.J., Sale, P.F., \& Heath, D.D. 2012. Local Retention, Dispersal and Fluctuating Connectivity among Populations of a Coral Reef Fish. Oecologia. 168(1): 61-71. doi: 10.1007/s00442-011-2058-1

Hughes, A.T.P., Baird, A.H., Dinsdale, E.A., Moltschaniwskyj, N.A., Pratchett, M.S., Tanner, E. \& Willis, B.L. 2000. Supply-Side Ecology Works Both Ways: The Link Between Benthic Adults, Fecundity and Larval Recruits. Ecolog. Mod. 81(8): 2241-2249.

Hughes, T.P., Rodrigues, M.J., Bellwood, D.R., Ceccarelli, D., Hoegh-Guldberg, O., McCook, L., Moltschaniwskyj, N., Pratchett, M.S., Steneck, R.S. \& Willis, B. 2007. Phase Shifts, Herbivory, and the Resilience of Coral Reefs to Climate Change. Current Biol. 17(4):360-365. doi: 10.1016/j.cub.2006.12.049

Hughes, T.P. \& Tanner, J.E. 2000. Recruitment Failure, Life Histories, and Long-Term Decline of Caribbean Corals. Ecolog. 81(8):2250. doi: 10.2307/177112

Husain, A.A.A. \& Gardiner, N.M. 2014. Ecological Assessment of Coral Reef Herbivorous Fish Assemblages across the Spermonde Archipelago. In The Indonesian Project Grants Workshop. Canberra.

Kelley, R. 2011. Indo Pacific Coral Finder. Australian Coral Reef Society.

Khalil, M. 2011. A Study of the Pelagic Larval Duration of Acropora humilis, Coral Recruitment and Connectivity in the Saudi Arabian. Thesis. King Abdullah Unversity of Science and Technology.

Kohler, K.E. \& Gill, S.M. 2006. Coral Point Count with Excel Extensions (CPCe): A Visual Basic Program for The Determination of Coral and Substrate Coverage using Random Point Count Methodology. Computer and Geoscience. 32:1259-1269. doi: 10.1016/j.cageo.2005. 11.009

McClanahan, T.R., Donner, S.D., Maynard, J.A., MacNeil, M.A., J Graham, N.A., Maina, J., Baker, A.C., Alemu, J.B., Beger, M., Campbell, S. J., Darling, E.S., Eakin, C.M., Heron, S.F., Jupiter, S.D., Lunquist, C.J., Mcleod, E., Mumby, P.J., Paddack, M J., Selig, E.R. \& Woesik, R.V. 2012. Prioritizing Key Resilience Indicators to Support Coral Reef Management in a Changing Climate. PLoS ONE, 7(8). doi: 10.1371/journal. pone.0042884
Moulding, A.L. 2005. Coral Recruitment Patterns in The Florida Keys. Revista de Biología Tropical 53: $75-82$.

Nemeth, M. \& Appeldoorn, R. 2009. The distribution of Herbivorous Coral Reef Fishes within ForeReef Habitats: The Role of Depth, Light and Rugosity. Caribbean J. Sci. 45(2-3): 247-253.

Obura, D. \& Grimsditch, G., 2009. Resilience assessment of coral reefs: assessment protocol for coral reefs, focusing on coral bleaching and thermal stress. Gland, Switzerland: IUCN.

Palupi, R.D., Siringoringo, R.M., \& Hadi, A. 2012. Status Rekruitmen Karang Scleractinia di Perairan Kendari Sulawesi Tenggara. IImu Kelautan. 17(3):170-175. doi: 10.14710/ik. ijms.17.3.170-175

Papu, A. 2011. Kondisi Tutupan Karang Pulau Kapoposang, Kabupaten Pangkajene Kepulauan, Provinsi Sulawesi Selatan. Jurnal IImiah Sains. 11(1):6-12

Russ, G.R. 2003. Grazer Biomass Correlates more Strongly with Production than with Biomass of Algal Turfs on a Coral Reef. Coral Reefs. 22 (1):63-67. doi: 10.1007/s00338-003-0286-5

Sawall, Y., Jompa, J., Litaay, M., Maddusila, A. \& Richter, C. 2013. Coral Recruitment and Potential Recovery of Eutrophied and Blast Fishing Impacted Reefs in Spermonde Archipelago, Indonesia. Mar. Poll. Bull.. 74(1):374-382. doi: 10.1016/j.marpolbul.20 13.06.022

Singkoh, M.F.O. 2010. Quantitative Data about Coral Recruitment from Bunaken Island, Manado Indonesia. Perikanan dan Kelautan. VI:67-71.

Suharsono. 2008. Jenis Jenis Karang di Indonesia. LIPI Press.

Trapon, M.L., Pratchett, M.S., \& Hoey, A.S. 2013. Spatial Variation in Abundance, Size and Orientation of Juvenile Corals Related to The Biomass of Parrotfishes on The Great Barrier Reef , Australia. PLoS ONE. 8(2):26-28. doi : 10.1371/journal.pone.0057788

Underwood, J.N., Wilson, S.K., Ludgerus, L. \& Evans, R.D. 2013. Integrating Connectivity Science and Spatial Conservation Management of Coral Reefs in North-West Australia. J. Nat. Conserv. 21(3):163-172. doi: 10.1016/j.jnc. 2012.12.001 